\title{
Understanding Plant Nitrogen Metabolism through Metabolomics and Computational Approaches
}

\author{
Perrin H. Beatty ${ }^{1, *}$, Matthias S. Klein ${ }^{2}$, Jeffrey J. Fischer ${ }^{2}$, Ian A. Lewis ${ }^{2}$, Douglas G. Muench ${ }^{2}$ \\ and Allen G. Good ${ }^{1}$ \\ 1 Department of Biological Sciences, University of Alberta, 85 Avenue NW, Edmonton, AB T6G 2E9, Canada; \\ allen.good@ualberta.ca \\ 2 Department of Biological Sciences, University of Calgary, 2500 University Drive NW, \\ Calgary, AB T2N 1N4, Canada; mklein@ucalgary.ca (M.S.K.); jfischer@roevin.ca (J.J.F.); \\ ian.lewis2@ucalgary.ca (I.A.L.); dmuench@ucalgary.ca (D.G.M.) \\ * Corresponding author: pbeatty@ualberta.ca; Tel.: +1-780-297-7044 \\ Academic Editor: Maurizio Chiurazzi \\ Received: 8 August 2016; Accepted: 30 September 2016; Published: 10 October 2016
}

\begin{abstract}
A comprehensive understanding of plant metabolism could provide a direct mechanism for improving nitrogen use efficiency (NUE) in crops. One of the major barriers to achieving this outcome is our poor understanding of the complex metabolic networks, physiological factors, and signaling mechanisms that affect NUE in agricultural settings. However, an exciting collection of computational and experimental approaches has begun to elucidate whole-plant nitrogen usage and provides an avenue for connecting nitrogen-related phenotypes to genes. Herein, we describe how metabolomics, computational models of metabolism, and flux balance analysis have been harnessed to advance our understanding of plant nitrogen metabolism. We introduce a model describing the complex flow of nitrogen through crops in a real-world agricultural setting and describe how experimental metabolomics data, such as isotope labeling rates and analyses of nutrient uptake, can be used to refine these models. In summary, the metabolomics/computational approach offers an exciting mechanism for understanding NUE that may ultimately lead to more effective crop management and engineered plants with higher yields.
\end{abstract}

Keywords: metabolomics; nitrogen; nitrogen use efficiency (NUE); transgenic crops; nitrogen uptake efficiency (NUpE); nitrogen utilization efficiency (NUtE); flux balance analysis (FBA); $\mathrm{N}$ boundary; mass spectrometry (MS); nuclear magnetic resonance (NMR)

\section{Introduction}

Nitrogen $(\mathrm{N})$ is a significant contributor to plant biomass and an essential component of most biomolecules. Nitrogen limitation frequently reduces crop growth and yield, and contributes to a variety of phenotypic changes including: expanded root architecture, reduced shoot biomass production, chlorosis, leaf discoloration, and impaired reproduction [1]. To ensure sufficient $\mathrm{N}$ for crop growth, farmers supplement fields with fertilizers containing nitrate $\left(\mathrm{NO}_{3}{ }^{-}\right)$, ammonium $\left(\mathrm{NH}_{4}{ }^{+}\right)$, or urea $\left(\mathrm{CO}\left(\mathrm{NH}_{2}\right)_{2}\right)$. Most crops take up approximately $40 \%$ of applied $\mathrm{N}$ [2], which results in environmental pollution in the form of aerosolized nitrous oxides and leaching of soluble nitrates into waterways [3-5]. Improving the nitrogen use efficiency (NUE) of crops might allow existing agricultural technologies to decrease the yield gap and therefore increase the necessary caloric intake of billions of people worldwide, and could diminish the impact of agriculture on the environment.

Efforts are currently underway to improve NUE through a variety of strategies. These include a critical evaluation of the method, timing, and management of fertilizer use as well as strategies for crop rotation and legislative changes to promote best management practices [2,6]. For example, 
Denmark now requires liquid fertilizers to be injected directly into the soil, which can reduce nitrogen volatilization by $41 \%$ [7]. In addition to these legislative actions, scientific investigations are ongoing to improve NUE though crop genetics. These efforts have included both traditional breeding programs and modern recombinant DNA technology (reviewed in [1,8-10]). One of these molecular approaches has resulted in crops achieving a higher NUE via the overexpression of alanine aminotransferase [8].

The success of modern molecular genetics has stimulated interest in adapting other state-of-the-art scientific strategies to this traditional agricultural problem. One advanced scientific approach with relevance to NUE is metabolomics. Many aspects of cellular metabolism have a direct impact on the uptake of nitrogen and partitioning of this element in tissues [11,12]. Given the significant resources required to develop transgenic crops $[13,14]$, it would be prudent to implement a technology that can directly evaluate the relationships between genetic change and nitrogen utilization. Decades of research have established detailed metabolic profiles of many crops [15], profiling the transcriptional response of $\mathrm{N}$ metabolism-related genes to diverse stimuli [16-19], and mapping of quantitative crop phenotypes to loci associated with metabolic genes [20-22]. Despite this wealth of information, the fundamental metabolic limitations of NUE remain unclear.

One major challenge in understanding NUE is the staggering scale of the metabolic networks of plants. There are thought to be more than 10,000 metabolites present in plants [23,24]. In addition, the metabolic activity of organisms is established through the combined action of numerous genes, chemical equilibria, and multiple layers of regulation. Consequently, unravelling the complex interactions between NUE and metabolism requires analytical approaches that can capture a comprehensive picture of steady-state metabolite concentrations and metabolic pathway fluxes.

Although extensive data is available on the metabolism of crop species [1,25], traditional analytical limitations have restricted metabolic investigations to a handful of metabolites per study. However, recent advances in analytical technology have dramatically increased the potential scope of metabolism research and have made comprehensive analyses of plant networks a feasible objective [26-30]. These metabolomics studies allow comprehensive data to be captured on the abundance of metabolites, activities of metabolic pathways, and physiological partitioning of nutrients. Herein, we describe recent advances in NUE research and discuss how metabolomics techniques could be harnessed to improve our understanding of NUE in crops.

\section{Discussion}

\subsection{Role of Metabolism in NUE}

Plant nitrogen uptake, assimilation and metabolism have been studied for over a century in regards to growth and yield of agriculturally important plants [8,31]. Perturbations in this essential physiological process have significant impact on the phenotypes of plants and elicit major changes in their metabolic networks. Nitrogen metabolism has been extensively examined in the context of $\mathrm{N}$ starvation ([11,26,32-34]; summarized in Table 1). Metabolic changes in plants are affected by length of the starvation period [23,24], tissue type [23], whether or not the plant is a cultivated variety [26,35], and developmental stage [11]. Not surprisingly, $\mathrm{N}$ starvation generally results in diminished levels of nitrogen containing metabolites (Table 1); this is most evident in normally abundant amino acids such as glutamate and glutamine. Depletion of these amino acids is generally correlated with elevated levels of organic acids from central carbon metabolism (Table 1). The metabolic composition is closely correlated, and tightly regulated, with plant biomass so that the metabolic composition can be a predictor (biomarker) of biomass [36]. Certain metabolites; carbon compounds from photosynthesis, starch and sucrose metabolism plus oxidative pentose phosphate pathway, tricarboxylic acid (TCA) cycle and glycolysis metabolites and N-containing metabolites such as glutamine, have been seen to be at low levels in plants undergoing high growth. This suggests that these metabolites are providing the major building blocks for biomass macromolecules such as proteins and that growth drives metabolism [36]. The majority of the plant's nitrogen stores are held as protein biomass or as inorganic 
nitrogen in the vacuoles. Consequently, the most effective NUE engineering strategies will likely target the flow of $\mathrm{C}$ and $\mathrm{N}$ through the metabolic network rather than focusing on concentrations of individual metabolites. Another theory regarding metabolites and growth suggests that the levels of some metabolites act as signaling molecules and regulate plant growth either positively or negatively. There are many metabolites of unknown structure that may be derived from primary metabolites to act as signaling molecules that should be studied further to understand this metabolite-growth interaction [36].

\subsection{Effect of Transgene Expression on Nitrogen Metabolism}

A common strategy for attempting to improve NUE has been to genetically modify plants [8-10]. Efforts have focused on (1) transgenes targeting $\mathrm{N}$ uptake and transport, such as ammonium transporters [37], proton gradient-forming ATPases [38], or peptide/nitrate transporters [39]; (2) transgenes directly involved in primary $\mathrm{N}$ metabolism such as cytosolic glutamine synthetase (GS1;1 and GS1;2) [40-42], plastidic glutamine synthetase (GS2) [43], glutamate synthase (GOGAT) [44], glutamate dehydrogenase (GDH, [45] or primary and secondary $\mathrm{N}$ metabolism such as transaminases like asparagine synthetase (AS1) [46] and alanine aminotransferase (AlaAT) [12]; (3) transgenes involved in $\mathrm{N}$ recycling such as autophagy-related factor 8c (ATG8c, [47]); (4) regulatory factors such as the transcription factor Dof1 [48,49], microRNA826 [50], or microRNA444 [51]; (5) or N-responsive transgenes of unknown function such as the early nodulin 93-like gene [52]. Although there have not been any detailed metabolomics studies involving plants with genetically engineered NUE phenotypes, several studies have examined specific metabolite levels, some of these studies are listed in Table 2 [12,41,46,48,49,52-54]). The studies in Table 2 demonstrated that over-expression of transgenes involved in nitrogen metabolism altered the levels of primary nitrogen compounds in certain tissues such as roots and shoots. However, in many of these studies, alteration of $\mathrm{N}$ metabolite levels either did not result in a subsequent NUE phenotype, or the potential NUE phenotype was not investigated. For example, GS1;1 and GS1;2 overexpression in rice (separately) increased core C and N metabolites in roots and shoots of plants grown at low $\mathrm{N}$, and the plants exhibited a low growth and low yield phenotype [41]. Therefore, overexpressing these glutamine synthetase genes unbalanced the C:N metabolic status in rice [41]. However, GS1 overexpression in wheat resulted in plants with increased total $\mathrm{N}$ in the grain and approximately $20 \%$ increase in grain yield [42]. Other transgenes, such as ENOD93 [52] and alaAT [12], showed increased levels of primary nitrogenous compounds and an NUE phenotype.

Previously, we suggested that manipulating regulatory pathways could provide a mechanism for improving NUE [55]. This hypothesis has been validated by He et al., who demonstrated that constitutive overexpression of miRNA826 and miR5090 repressed expression of glucosinolate synthesis-related genes while N starvation-responsive genes were upregulated [50]. Transgenic Arabidopsis expressing these miRNAs showed enhanced tolerance to low $\mathrm{N}$, increased biomass, increased lateral root production, increased chlorophyll, and decreased anthocyanin content relative to the wildtype (WT) [50]. Likewise, overexpression of the Zea mays transcription factor Dof1 in rice caused increased phosphoenolpyruvate carboxylase (PEPc) expression as well as altered expression of TCA-related genes. Moreover, these expression changes were correlated with changes in TCA cycle intermediates, such as malate, citrate, and isocitrate [49]. Enhanced growth under limiting N, increased photosynthesis rate, and decreased shoot-to-root ratio was also observed [49]. Along these lines, overexpression of PEPc in Vicia narbonensis seedlings resulted in increased $C$ and $N$ content [56]. Increasing photosynthetic production by bioengineering crops is not only important for increased carbon sequestration [57] and biofuel production [58], but may also provide enhanced NUE as a result. Transgenic lines with increased photosynthetic capacity should therefore be evaluated in terms of nitrogen use efficiency as well, and vice-versa. 
Table 1. Effect of nitrogen starvation on the metabolome of photosynthesizers.

\begin{tabular}{|c|c|c|c|c|c|c|c|c|c|}
\hline Species & $\begin{array}{l}\text { Synechocystis sp. } \\
\text { PC } 6803\end{array}$ & $\begin{array}{l}\text { Chlamydomos } \\
\text { reinhardtii }\end{array}$ & $\begin{array}{c}\text { Chlamydomonas } \\
\text { reinhardtii }\end{array}$ & \multicolumn{2}{|c|}{ Arabidopsis thaliana } & \multicolumn{2}{|c|}{ Zea mays } & \multicolumn{2}{|c|}{ Zea mays } \\
\hline $\begin{array}{l}\mathrm{N} \text { depletion condition: length of } \\
\text { time and concentration shift }\end{array}$ & $4 \mathrm{~h} ; 5$ to $0 \mathrm{mM} \mathrm{NH}_{4}^{+}$ & $24 \mathrm{~h} ; 7$ to $0 \mathrm{mM} \mathrm{NH}_{4}^{+}$ & $\begin{array}{c}1,2,6 \text { days; } \\
7.48 \text { to } 0 \mathrm{mM} \mathrm{NH}_{4}^{+}\end{array}$ & \multicolumn{2}{|c|}{$\begin{array}{c}0,2,10 \text { days; } \\
\left.6 \text { to } 0 \mathrm{mM} \mathrm{NO}_{3}^{-}\right)\end{array}$} & \multicolumn{2}{|c|}{$\begin{array}{l}\text { Inbred lines } \mathrm{A} 188, \mathrm{~B} 73 ; \\
0.15 \text { or } 15 \mathrm{mM} \mathrm{NO}_{3}^{-}\end{array}$} & \multicolumn{2}{|c|}{$\begin{array}{c}\text { Inbred line } \mathrm{B}^{2} 0^{0.1} \text { or } \\
10 \mathrm{mM} \mathrm{NO}_{3}^{-}\end{array}$} \\
\hline $\begin{array}{l}\text { Technique } \\
\text { Reference }\end{array}$ & CE-MS, LC-MS/MS & GC-TOF-MS & GC-MS & \multicolumn{2}{|c|}{ GC-MS, anion HPLC } & \multicolumn{2}{|c|}{$\begin{array}{l}\text { GC-MS } \\
{[26]}\end{array}$} & \multicolumn{2}{|c|}{$\begin{array}{l}\text { GC-MS } \\
\text { [11] }\end{array}$} \\
\hline Metabolite & & & $1-2-6 \mathrm{~d}$ & Shoot & Root & A188 & B73 & Veg. & Mat. \\
\hline \multicolumn{10}{|c|}{ Amino Acids (percentages, $\%$ ) } \\
\hline Alanine & 200 & 6 & $44-87-64$ & $66-27$ & $86-84$ & $11-15$ & $28-40$ & 18 & 18 \\
\hline Arginine & 48 & & $129-97-65$ & & & $14-51$ & $97-82$ & 26 & \\
\hline Asparagine & 55 & 18 & & $64-20$ & $163-24$ & $11-85$ & $32-78$ & 1 & \\
\hline Aspartate & 21 & 63 & $21-17-14$ & $44-27$ & $48-32$ & $28-52$ & $45-163$ & 4 & \\
\hline Cysteine & & 135 & & & & $58-57$ & $72-83$ & & \\
\hline Glutamate & 88 & 18 & $21-72-57$ & $68-54$ & $82-29$ & $27-50$ & $57-62$ & 12 & \\
\hline Glutamine & 43 & 10 & $58-50-56$ & & & & $25-96$ & 3 & \\
\hline Glycine & 262 & 35 & $76-161-86$ & $56-22$ & $178-706$ & $8-38$ & $21-131$ & 3 & \\
\hline Histidine & 136 & 55 & & & & & & & \\
\hline Isoleucine & 576 & 250 & $38-42-29$ & $116-67$ & $103-90$ & $48-40$ & $61-49$ & 14 & \\
\hline Leucine & 688 & 59 & $25-21-14$ & $139-70$ & $97-78$ & $56-38$ & $84-34$ & & 40 \\
\hline Lysine & 124 & 42 & $28-62-58$ & $84-37$ & $106-72$ & $77-84$ & $198-91$ & 26 & 54 \\
\hline Methionine & 241 & 18 & $146-201-215$ & & & & & & 32 \\
\hline Phenylalanine & 433 & 44 & $16-25-11$ & $129-66$ & 73-44 & $49-42$ & $64-40$ & 19 & \\
\hline Proline & 198 & 34 & 71-49-95 & $72-23$ & $73-38$ & $40-57$ & $70-65$ & 8 & \\
\hline Serine & 472 & 14 & $21-61-42$ & $134-75$ & $86-57$ & $11-31$ & $25-86$ & 3 & \\
\hline Threonine & 349 & 246 & $38-187-95$ & $81-46$ & $97-46$ & $25-28$ & $47-74$ & 6 & 26 \\
\hline Tryptophan & 83 & 495 & $8-24-6$ & & & $88-53$ & $74-52$ & 62 & \\
\hline Tyrosine & 1284 & 111 & $24-51-26$ & $171-92$ & $103-90$ & $40-54$ & $71-61$ & 21 & 40 \\
\hline Valine & 235 & 33 & $40-57-50$ & $91-66$ & $103-90$ & $44-47$ & $58-61$ & 10 & \\
\hline \multicolumn{10}{|c|}{ Organic Acids (percentages, \%) } \\
\hline Aconitate & 115 & & & $55-30$ & $102-65$ & & & 45 & 45 \\
\hline Benzoate & & 73 & $43-114-102$ & $92-85$ & $64-90$ & & & & \\
\hline Citrate & 59 & 56 & 133-1478-1134 & $59-25$ & $156-45$ & & & & 886 \\
\hline Erythonate & & & & $134-242$ & $113-120$ & & & 50 & 48 \\
\hline Fumarate & 1015 & 16 & $33-125-95$ & $442-397$ & $94-67$ & $41-78$ & $51-68$ & 52 & 135 \\
\hline Glycerate & 141 & 58 & $40-48-46$ & $172-67$ & $1209-5301$ & & & & \\
\hline 2-oxoglutarate & 360 & 46 & $95-45-114$ & $105-86$ & $152-97$ & $80-95$ & $108-45$ & & \\
\hline Lactate & & & $39-63-54$ & $109-130$ & $22-52$ & & & & \\
\hline Malate & 876 & 26 & $34-87-82$ & $113-97$ & $993-461$ & $34-20$ & $23-23$ & 61 & \\
\hline Maleate & & & $28-56-148$ & $157-182$ & $84-85$ & & & 900 & \\
\hline Oxaloacetate & & 94 & $1-36-1$ & $160-83$ & $125-192$ & & & & \\
\hline Pyruvate & 334 & 25 & $21-27-100$ & $81-75$ & $71-106$ & $75-50$ & $81-34$ & & 11 \\
\hline Shikimate & 168 & 40 & & $103-77$ & $160-53$ & $170-216$ & $131-312$ & 26 & \\
\hline Succinate & 398 & 81 & $97-216-167$ & $178-346$ & $114-67$ & & & & \\
\hline Threonate & & 39 & 96-131-111 & $99-132$ & $267-238$ & & & & \\
\hline
\end{tabular}


Table 1. Cont

\begin{tabular}{|c|c|c|c|c|c|c|c|c|c|}
\hline \multirow[t]{2}{*}{ Species } & \multirow[t]{2}{*}{$\begin{array}{c}\text { Synechocystis sp. } \\
\text { PC } 6803\end{array}$} & \multirow[t]{2}{*}{$\begin{array}{l}\text { Chlamydomos } \\
\text { reinhardtii }\end{array}$} & \multirow{2}{*}{$\begin{array}{c}\begin{array}{c}\text { Chlamydomonas } \\
\text { reinhardtii }\end{array} \\
\text { ols and Sugars (pe }\end{array}$} & \multicolumn{2}{|c|}{ Arabidopsis thaliana } & \multicolumn{2}{|c|}{ Zea mays } & \multicolumn{2}{|c|}{ Zea mays } \\
\hline & & & & \multicolumn{6}{|c|}{ Alcohols and Sugars (percentages, \%) } \\
\hline Glycerol & & 77 & $1.6-0.9-0.5$ & $100-93$ & $64-70$ & & & & \\
\hline Inositol & & 13 & $30-52-84$ & $97-74$ & $177-258$ & & & 67 & \\
\hline Fructose & & & $312-202-97$ & $462-218$ & $687-277$ & $44-34$ & $29-31$ & 11 & \\
\hline Galactose & & & $17-7-7$ & $343-487$ & 208-225 & & & 30 & 15 \\
\hline Glucose & & & $27-10-3$ & $405-545$ & $413-515$ & $30-21$ & 29-24 & 6 & \\
\hline Maltose & & 62 & & 95-93 & $79-86$ & & & 121 & \\
\hline Mannose & & & & 223-184 & $132-362$ & & & 16 & 24 \\
\hline Raffinose & 183 & & & 973-7981 & $198-313$ & $275-268$ & $270-159$ & 333 & \\
\hline Sucrose & & & & $89-89$ & $99-110$ & & & & 71 \\
\hline Xylose & & & 67-195-231 & $119-149$ & $271-357$ & & & & \\
\hline \multicolumn{10}{|c|}{ Phosphorylated Compounds (percentages, \%) } \\
\hline 6-phosphogluconic acid & 136 & 6 & $120-177-171$ & & & & & & \\
\hline Fructose-6P: Fru-6P & 148 & 64 & $20-44-73$ & $65-55$ & $76-65$ & $72-296$ & $137-526$ & 21 & \\
\hline Fructose-1,6-bisP & 82 & 67 & & & & & & & \\
\hline Glucose-1-P & 119 & 61 & & & & & & & \\
\hline Glucose-6-P & 148 & 89 & 53-99-44 & $70-57$ & $88-84$ & $77-356$ & $131-559$ & 14 & \\
\hline Glycerate-3P & 139 & 161 & $52-230-83$ & & & & & 11 & 150 \\
\hline myo-inositol-P & & & $108-83-71$ & $148-77$ & $66-70$ & & & & \\
\hline Phosphoenol-pyruvate & 104 & 19 & & & & & & & \\
\hline Ribulose-5P & 127 & 99 & & & & 69-174 & $100-333$ & & \\
\hline \multicolumn{10}{|c|}{ Nitrogenous Compounds (percentages, \%) } \\
\hline$\gamma$-aminobutyric acid & 536 & & $167-114-43$ & $204-138$ & $217-96$ & $29-25$ & $38-39$ & 8 & \\
\hline Adenine & 100 & 9 & $24-52-56$ & & & & & & \\
\hline Citrulline & 23 & 23 & & & & $11-73$ & $23-138$ & & \\
\hline Hydroxylamine & & 139 & $114-81-72$ & $59-8$ & $19-34$ & & & & \\
\hline Ornithine & 21 & 6 & $127-87-59$ & & & $10-72$ & $48-94$ & & \\
\hline Putrescine & & 9 & $11-13-8$ & & & & & 12 & 9 \\
\hline Uracil & & 10 & $13-17-18$ & & & & & & \\
\hline
\end{tabular}


Table 2. Effect of transgene expression on metabolite levels in transgenic plants.

\begin{tabular}{|c|c|c|c|c|}
\hline Genetic Construct & Conditions & Technique & Core Metabolomic Results (Compared to WT) & References \\
\hline \multicolumn{5}{|c|}{$\mathrm{N}$ metabolism } \\
\hline $\begin{array}{l}\text { Oryza sativa GS1;1 and GS1;2 overexpressed in } \\
\text { Oryza sativa cv. Zhonghua } 11 \text { under the control } \\
\text { of the CaMV } 35 S \text { promoter }\end{array}$ & $\begin{array}{l}\text { Metabolic analysis done on tillering stage roots } \\
\text { and shoots of plants growth with Low } \mathrm{N} \text { and } \\
\text { Moderate } \mathrm{N}\end{array}$ & GC-TOF-MS & $\begin{array}{l}\text { Low N: GS1;1 and GS1; } 2 \text { increased sugars, organic acids, } \\
\text { free amino acids in shoots and decreased in roots. } \\
\text { Moderate N: same results for both lines in shoots as for } \\
\text { low N, in roots GS1;1 increased sugars, organic acids and } \\
\text { free amino acids GS1;2 roots had decreased metabolites. }\end{array}$ & [41] \\
\hline $\begin{array}{l}\text { Pisum sativum AS1 overexpressed in } \\
\text { Nicotiana tabacum under the control of the } \\
\text { CaMV } 35 S \text { promoter }\end{array}$ & $\begin{array}{l}16 \mathrm{~h} \text { light } / 8 \mathrm{~h} \text { dark, } 21 \text { day old plants grown in } \\
\text { sand, fertilized with Hoagland solution with } 10 \\
\mathrm{mM} \mathrm{NO}_{3}{ }^{-}\end{array}$ & HPLC & $\begin{array}{l}10-100 \text { fold increased Asn. } \\
\text { Decreased Gln, Asp. } \\
\text { No change in Glu. }\end{array}$ & [46] \\
\hline $\begin{array}{l}\text { Hordeum vulgare AlaAT overexpressed in } \\
\text { Oryza sativa under the control of the } \\
\text { root-specific OsANT1 promoter }\end{array}$ & $\begin{array}{l}14 \mathrm{~h} \text { light } / 10 \mathrm{~h} \text { dark, } 45 \text { day old plants grown } \\
\text { hydroponically in } 0.5,2.0 \text {, } \\
\text { and } 5.0 \mathrm{mM} \mathrm{NH}_{4}^{+}\end{array}$ & HPLC & Increased Gln, Glu, Asn, Asp, and Arg in roots and shoots. & [12] \\
\hline \multicolumn{5}{|c|}{$\mathrm{N}$ recycling/protein degradation/C:N balance } \\
\hline $\begin{array}{l}\text { Mus musculus ODC overexpressed in } \\
\text { Populus nigra under the control of a } 2 \mathrm{X} \\
\text { CaMV } 35 \text { S promoter }\end{array}$ & Cell cultures grown in MS media & HPLC & $\begin{array}{l}\text { Increased Ala, Thr, Val, Ile, and GABA. } \\
\text { Decreased Gln, Glu, Orn, Arg, His, Ser, Gly, Cys, Phe, Trp, } \\
\text { Asp, Lys, Leu, Met. }\end{array}$ & [53] \\
\hline $\begin{array}{l}\text { Arabidopsis FUM2 overexpressed in Arabidopsis } \\
\text { under the control of a } 2 \mathrm{X} \text { CaMV } 35 S \text { promoter }\end{array}$ & $\begin{array}{l}8 \mathrm{~h} \text { light } / 16 \mathrm{~h} \text { dark, plants grown for } \\
42 \text { days with } 1.25 \mathrm{mg} \text { (low) or } 31.5 \mathrm{mg} \text { (high) } \\
\text { inorganic nitrogen }\end{array}$ & GC-MS & $\begin{array}{l}\text { Increased starch, FUM2 knockouts reduced fumarate } \\
\text { levels, varied amino acid levels according to light cycle. }\end{array}$ & [54] \\
\hline \multicolumn{5}{|c|}{ Regulatory transgenes } \\
\hline $\begin{array}{l}\text { Zea mays Dof } 1 \text { expressed in Arabidopsis under } \\
\text { the control of the CaMV } 35 \mathrm{~S} \text { promoter; } \\
\text { also expressed in potato }\end{array}$ & $\begin{array}{l}\text { Constant light, plants grown on modified MS } \\
\text { medium; low } \mathrm{N}=1 \mathrm{mM} \mathrm{NH} \mathrm{mO}_{3} / 1 \mathrm{mM} \mathrm{KNO}_{3} ; \\
\text { high } \mathrm{N}=10 \mathrm{mM} \mathrm{NH} \mathrm{NO}_{3} / 10 \mathrm{mM} \mathrm{KNO}_{3}\end{array}$ & $\begin{array}{l}\text { Hitachi amino acid analyzer; } \\
\text { enzymatic assay }\end{array}$ & $\begin{array}{l}\text { Increased total [amino acid], } \mathrm{NH}_{4}{ }^{+} \text {Decreased } \\
\text { glucose, malate } \\
\text { No change in sucrose, citrate, or 2-OG } \\
\text { Similar to transgenic potato }\end{array}$ & [48] \\
\hline $\begin{array}{l}\text { Zea mays Dof1 expressed in Oryza sativa under } \\
\text { the control of the CaMV } 35 \text { S promoter }\end{array}$ & $\begin{array}{l}14 \mathrm{~h} \text { day } / 10 \mathrm{~h} \text { night, hydroponic growth at } \\
360 \text { (high) or } 90 \mu \mathrm{M} \text { (low) } \mathrm{NH}_{4}^{+}\end{array}$ & CE-MS/MS & $\begin{array}{l}\text { Increased concentration of some amino acids under high } \\
\text { and low }[\mathrm{N}]\end{array}$ & [49] \\
\hline \multicolumn{5}{|c|}{ N-responsive transgenes } \\
\hline $\begin{array}{l}\text { Oryza sativa ENOD93 expressed in Oryza sativa } \\
\text { under the control of the } 35 S \text { C4PDK promoter }\end{array}$ & $\begin{array}{l}16 \mathrm{~h} \text { day } / 8 \mathrm{~h} \text { night for } 4 \text { weeks then } \\
10 \mathrm{~h} \text { day } / 14 \mathrm{~h} \text { night for } 1 \text { week for flowering, } \\
\text { soil growth at } 1 \mathrm{mM} \text { (low), } 5 \mathrm{mM} \text { (median) or } \\
10 \mathrm{mM} \text { (high) nitrate }\end{array}$ & Biochemical assays & $\begin{array}{l}\text { Increased total amino acids in OsENOD93-ox line roots in } \\
\text { all N levels but more so under } \mathrm{N} \text { stress. No increase in } \\
\text { amino acid levels in shoots. Higher biomass in } \\
\text { OsENOD93-ox. }\end{array}$ & [52] \\
\hline \multicolumn{5}{|c|}{ Co-expressed N metabolism and Regulatory transgenes } \\
\hline $\begin{array}{l}\text { Arabidopsis Dof1, GS1, GS2 expressed in } \\
\text { tobacco under the control of the leaf specific } \\
\text { rbcS promoter from tomato }\end{array}$ & $\begin{array}{l}\text { Growth in perlite and low } \mathrm{N} \text { nutrient solution } \\
\text { for } 60 \text { and } 90 \text { days }\end{array}$ & RP-HPLC and biochemical assays & $\begin{array}{l}\text { Transgenic tobacco co-expressing Dof1, GS1, } \\
\text { GS2 had increased amino acids, glucose, sucrose and } \\
\text { decreased nitrate, malic acid, citric acid and showed } \\
\text { growth advantages }\end{array}$ & [43] \\
\hline
\end{tabular}


Several studies have suggested a link between photosynthate production (the saccharide products of carbon fixation) and NUE. Photosynthates are stored as a variety of polysaccharides including: starch, cellulose, hemicellulose, pectin, and lignin [59]. These polysaccharides are synthesized from nucleotide diphosphate-sugar (NDP-sugar) moieties such as UDP- $\alpha$-D-glucose, which is a major component of cellulose, synthesized from fructose-6-phosphate, itself a product of photosynthesis [59]. Under N-limiting conditions, both Arabidopsis and rice show that genes encoding UDP-glucose 4-epimerases are differentially expressed [60,61], while the addition of $\mathrm{N}$ results in decreased expression of genes involved in cellulose biosynthesis [62]. Moreover, Guevara et al. recently showed that overexpression of the rice UDP-glucose 4-epimerase OsUGE1 led to increased sucrose and decreased cellulose production under nitrogen limiting conditions [63]. Similarly, overexpression of OsUGE1 in Arabidopsis resulted in drought, freezing, and salinity tolerance, which was attributed to elevated raffinose content [64]. This observation is consistent with a variety of studies that have reported similar phenotypes under N-limiting conditions (Table 1). Another study by Li et al. [65] demonstrated that transgenic Arabidopsis plants that overexpressed Larix gmelinii UDP-glucose pyrophosphorylase showed more rapid vegetative growth compared to wild-type plants, and had greater soluble sugar and cellulose levels [65]. An inverse relationship between the distribution of photosynthate into cell wall materials (such as lignins), and the nitrogen supply [66] suggests that there is an increase in carbon skeleton demand during nitrogen assimilation. This suggests that promoting carbon skeleton production for $\mathrm{N}$ assimilation through genetic manipulation may be an attractive means to enhance NUE. This diverse list of genes and gene products associated with the $\mathrm{C}: \mathrm{N}$ balance in plants and hence biomass and yield shows the genetic complexity involved with improving NUE in plants. It is highly likely that a stacking transgenic approach, where two or more C:N metabolism-associated genes are coordinately over- or differently-expressed, would provide the correct metabolic balance for an NUE phenotype [8,9]. For example, when Wang et al. [43] co-expressed Dof1, GS1 and GS2 in tobacco, the transgenic plants had increased amino acids and sugars, decreased nitrate, malic acid and citric acid, and they exhibited a growth advantage over wild-type tobacco under low $\mathrm{N}$ conditions.

A wide variety of molecular genetic studies have demonstrated a significant association between carbohydrate metabolism and NUE. Moreover, these studies indicate that a more comprehensive understanding of plant metabolism could provide insight into directed approaches for engineering improved NUE. One of the major barriers to achieving this outcome is the difficulty in predicting the identity of genes that will have a positive impact on NUE metabolism. Metabolomics offers a promising solution for understanding the metabolic effects of genetic modification and possibly guiding NUE crop engineering.

\subsection{Metabolomics Technology}

The goal of metabolomics is to understand metabolic networks on a comprehensive scale by identifying and quantifying all of the metabolites present in biological extracts. This systems-level objective requires elements of traditional biology, analytical chemistry, computer science, and statistics. Although the relative weighting of these disciplines varies from study to study, most metabolomics investigations can be framed as follows: (1) a biologically relevant phenotype is identified; (2) metabolites are extracted from the relevant tissue(s); (3) observable metabolites are identified and quantified using a mixture of bioinformatics and bioanalytical approaches; and (4) metabolic phenomena associated with the biological phenotype are identified by statistical or computational analyses. The details of how to implement this strategy in plant-based metabolomics studies have been extensively reviewed elsewhere [67]. Herein, we will discuss the challenges and opportunities of metabolomics in NUE-related research.

One important consideration in adapting the emerging metabolomics technology to NUE is the significant role that analytical tools play in shaping experimental design and the impact these tools have on the nature and volume of data that are ultimately generated. Most metabolomics studies are conducted using nuclear magnetic resonance (NMR) spectroscopy or mass spectrometry 
(MS), as evidenced by PubMed title/abstract searches using the key words "metabolomics" or "metabolomics" and "NMR" and "MS".

The primary advantages of NMR are that its signals are directly proportional to concentration, and that it can detect virtually any molecule that is present above its sensitivity limit. These attributes are valuable in NUE studies because they allow one to account for all the carbon and nitrogen flowing into and out of systems, to investigate networks with no prior information about the organism's metabolic architecture, and to unambiguously assign novel molecules. Moreover, NMR can detect ${ }^{13} \mathrm{C}$ and ${ }^{15} \mathrm{~N}$-containing molecules. Consequently, labeling studies employing these stable isotopes allows for the measurement of carbon and nitrogen utilization in plants [68]. Figure 1 shows a multidimensional ${ }^{1} \mathrm{H}^{-13} \mathrm{C}$ NMR spectrum of Medicago sativa seedlings that illustrates a typical complement of metabolites observed in an untargeted NMR-based assay. Detailed descriptions on the method of collection and interpretation of these NMR data have been published elsewhere [69-71]. Additionally, in vivo NMR can be used to analyze metabolic pathway activity and metabolite compartmentalization in living plants [72-74]

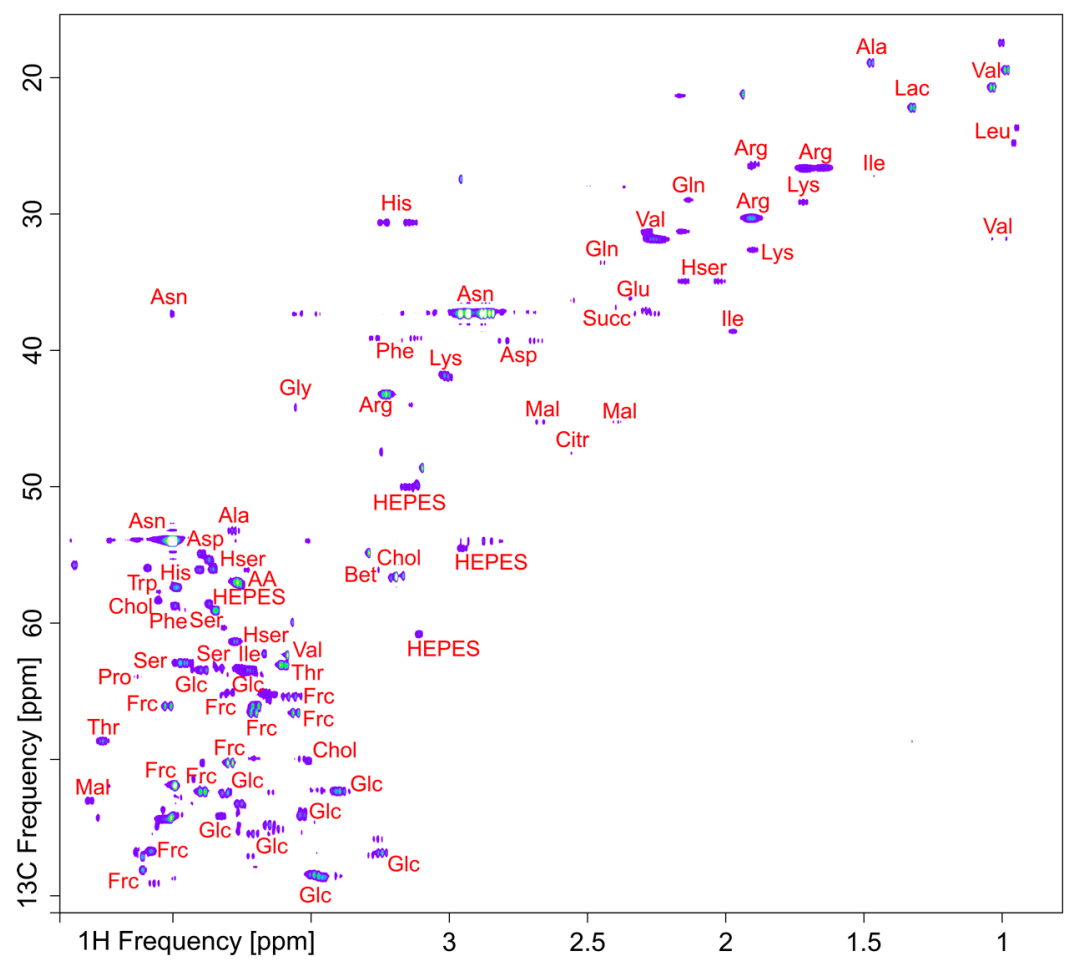

Figure 1. Multi-dimensional ${ }^{1} \mathrm{H}_{-}{ }^{13} \mathrm{C}$ NMR spectrum of aqueous extracts from Medicago sativa seedlings illustrating a typical complement of metabolites observed in untargeted NMR.

The primary advantage of mass spectrometry is its high sensitivity. Whereas NMR is restricted to analyses of the 20 to 50 most abundant compounds, MS can detect hundreds or even thousands of molecules per sample. This is invaluable for understanding metabolic networks on a comprehensive scale and can detect potent low-abundant compounds, such as hormones [75]. MS's ability to investigate metabolic activity makes it a powerful tool for linking metabolism to genes. Recently, a variety of genes have been identified by coupling modern metabolomics methods to quantitative trait locus mapping (mQTL) [76]. This hybrid metabolomics/genomics approach offers a powerful mechanism for decoding the polygenic contributions to NUE phenotypes. Moreover, MS is inherently well-adapted to measuring isotope incorporation into metabolic intermediates. Consequently, MS is frequently used for quantitative analysis of pathway flux, elucidating metabolic network architecture, and determining metabolic partitioning through the 
network. While MS can provide data on overall isotope incorporation of (low-abundance) metabolites, NMR can be used to further refine this information (for the more abundant metabolites) by providing the molecular positions of the labels. This information can be used to unambiguously assign the pathways that were used to synthesize the compounds in questions [77-79]. The use of MS to trace isotope labelling is illustrated in Figure 2, which shows the accumulation of ${ }^{15} \mathrm{~N}$-labelled amino acids in barley leaves after exposure to ${ }^{15} \mathrm{~N}$-labelled $\mathrm{KNO}_{3}$. The rates at which ${ }^{15} \mathrm{~N}$ accumulates is dependent on the metabolic pathways used to synthesize the compounds and are thus a direct measure of pathway activity. This data can be used to trace the connectivity of complex metabolic networks.
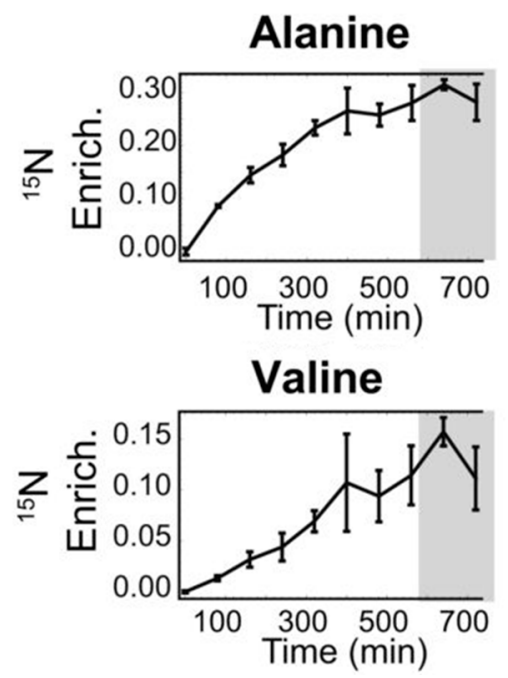

Figure 2. ${ }^{15} \mathrm{~N}$ enrichment levels of two amino acids in barley leaves provided with ${ }^{15} \mathrm{~N}$-labelled $\mathrm{KNO}_{3}$, as determined by gas chromatography-mass spectrometry (GC-MS). Light periods are marked in white and dark periods in gray. Adapted with permission from [78].

\subsection{Metabolic Flux Analysis}

Metabolic data can be divided into two major categories: steady-state and flux. Steady-state data reflect metabolite concentrations, whereas fluxes indicate the rates at which metabolites are used and consumed. Nitrogen use efficiency is inherently related to flux rather than steady-state metabolism. The combination of NMR and MS offers a powerful opportunity to understand nitrogen metabolism from a flux perspective and to identify the most effective mechanisms for improving the nitrogen used by plants.

Significant research has been devoted to understanding metabolic flux in biological systems through computational analysis. Flux balance analysis (FBA) is one of the most powerful and convenient of these approaches [80]. In contrast to traditional enzyme kinetics, FBA does not require detailed information about enzyme properties, concentrations of intermediates, or protein levels. Consequently, FBA provides insight into network dynamics without relying on these difficult-to-obtain data. When coupled with FBA, metabolomics offers a powerful mechanism for constructing and refining models of complex systems.

FBA analyses are performed by constructing a computational model of the metabolic network. This model includes a stoichiometry matrix, which describes all of the reactants and products involved in each reaction, and a flux vector representing all of the metabolic activity in the network. The goal of FBA is to find an optimal set of fluxes to achieve a particular objective [81] (see Figure 3 for an example). In the context of NUE, this may include maximizing biomass production with minimal $\mathrm{N}$ usage. Flux balance problems are generally solved by introducing constraints into the system, the most common of which is the steady-state assumption [79,80]. In addition, the system can be further constrained by establishing boundary fluxes, or the rates at which molecules enter and leave 
the system. Metabolomics is particularly useful in this context because it allows one to directly quantify boundary fluxes and to establish empirical constraints on metabolic partitioning within the network [82].
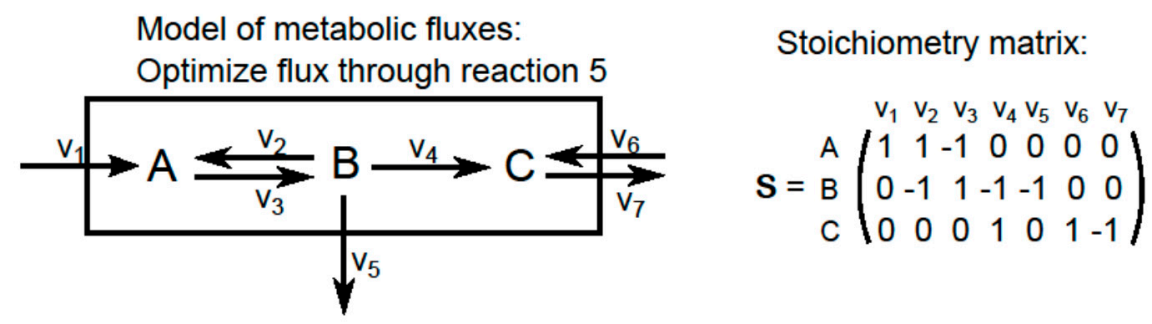

Find solutions for: $\max (Z)=\max \left(v_{5}\right)$

Figure 3. Example of a simple metabolic flux model and the equations for defining a flux balance analysis to maximize flux through reaction 5 .

FBA has been used extensively to analyze nitrogen uptake in single cell systems such as E. coli [83]. However, analyses of whole plants are significantly more complex due to the significant differences in metabolism between organs, development stage, and complex environmental interactions. However, several groups have taken up this challenge, and FBA has now been used to elucidate the complex metabolic networks of plants and their symbionts [84-87]. A recent FBA study took a first step toward unraveling this complexity by incorporating two distinct types of plant cells (mesophyll and bundle sheath) and their interactions [88]. This approach has since been used to analyze nitrogen availability in the maize leaf [89]. Moreover, FBA has recently been performed using a whole-plant dynamic model of barley [25]. This model incorporated detailed flux maps of leaf, stem and seeds as well as simplified models of roots and phloem, and used further constraints predicted by functional plant models (FPM) [90].

In summary, recent studies have shown that plant metabolism can be understood through computational models. In general, these models have been reliant on computational predictions of metabolic constraints. Consequently, metabolomics offers a direct mechanism for advancing these state-of-the-art computational approaches. We anticipate that empirical measures of boundary fluxes and metabolic architecture defined by isotope-based studies will dramatically improve the quality and scope of these analyses.

\subsection{Modeling Fluxes in NUE}

Despite the recent developments in FBA of whole-plant metabolism, NUE has yet to become the focus of such efforts. Herein, we present a theoretical framework for a whole plant model of NUE and discuss the role that metabolomics could play in constructing this model.

Nitrogen use efficiency can be compartmentalized into nitrogen uptake efficiency (NUpE) and nitrogen utilization efficiency (NUtE). NUpE is the plant's ability to take up fixed N from the soil and is both genetically and environmentally regulated. Plants can only use fixed, biologically reactive, nitrogen in $\mathrm{N}$ metabolism. Fixed $\mathrm{N}$ is available to plants as peptides and amino acids from decomposing organic matter and as $\mathrm{NO}_{3}{ }^{-}$and $\mathrm{NH}_{4}{ }^{+}$from soil microbes and synthetic and organic fertilizers. NUtE can be further defined as $\mathrm{N}$ assimilation and $\mathrm{N}$ remobilization. $\mathrm{N}$ assimilation is the plant's ability to reduce nitrate to ammonia and use it as a substrate in the primary $\mathrm{N}$ metabolism reactions catalyzed by nitrate and nitrite reductases, glutamine synthetase and glutamate synthase. These reactions 
assimilate $\mathrm{N}$ into glutamine and glutamate, which are then used as $\mathrm{N}$ sources to produce other amino acids via amino transferases. These $\mathrm{N}$ compounds are translocated to the shoots and eventually remobilized and stored as $\mathrm{N}$ sinks in order to be a fixed $\mathrm{N}$ source for the embryo in the seed [8,91].

The $\mathrm{N}$ inputs, the $\mathrm{N}$ flow though the plant, the $\mathrm{N}$ loss outputs and the $\mathrm{N}$ sinks can be measured as $\mathrm{N}$ boundary fluxes $\left(\mathrm{V}_{1}\right.$ to $\mathrm{V}_{9}$ in Figure 4$)$ using NMR techniques, and specific $\mathrm{N}$ metabolites can be traced through the system using MS techniques (Figure 2). Figure 4 shows the defined $\mathrm{N}$ fluxes for a field-grown cereal crop. The potential sources of $N$ input are defined as $V_{1}, V_{5}$ and $V_{6}$ (blue arrows), the potential sources of $\mathrm{N}$ loss (outputs) are $\mathrm{V}_{2}, \mathrm{~V}_{3}, \mathrm{~V}_{4}, \mathrm{~V}_{7}$, and $\mathrm{V}_{10}$ (red arrows) and the $\mathrm{N}$ sinks are $V_{8}$ and $V_{9}$ (green arrows). $N$ volatilization $\left(V_{2}\right)$ may be measured by means of headspace gas chromatography to further refine the model of boundary fluxes in the system. Together, these $\mathrm{N}$ flux data can provide valuable insight on the fate of $\mathrm{N}$ in the system, and identify flux changes when comparing wild-type and transgenic plants.

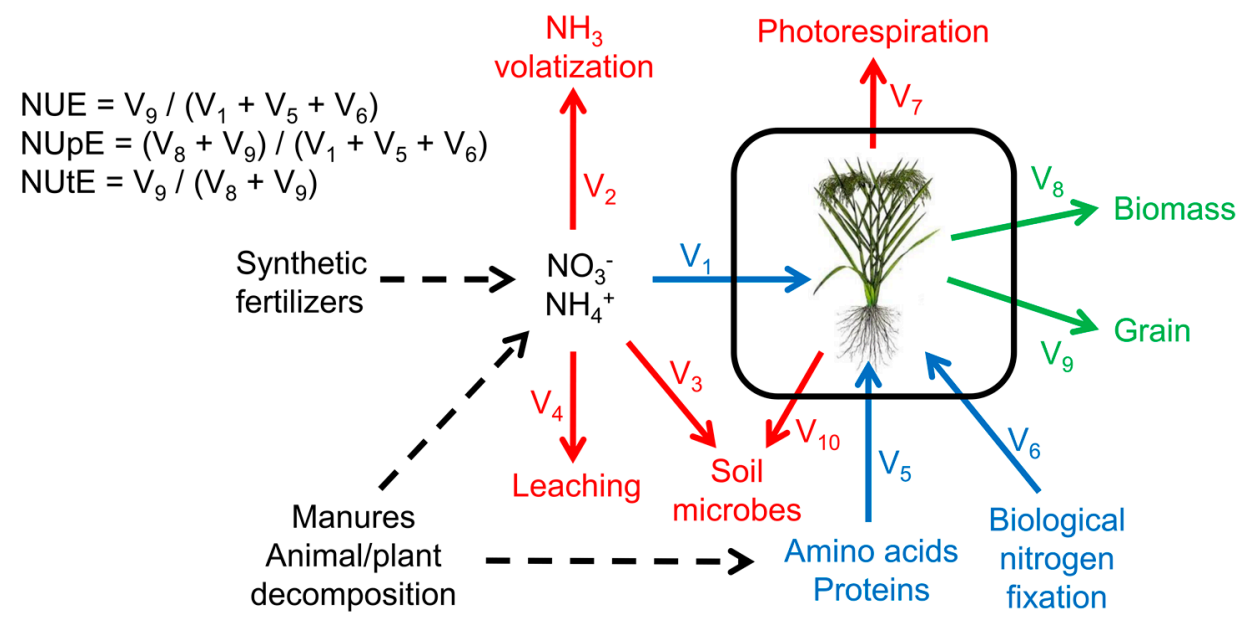

Figure 4. A simplified model of boundary fluxes in nitrogen use of crop plants. NUE: Nitrogen use efficiency, NUpE: Nitrogen uptake efficiency, NUtE: Nitrogen utilization efficiency.

\section{Conclusions}

Recent advances in mass spectrometry and nuclear magnetic resonance spectroscopy have revealed the potential of using metabolomics to unravel metabolic networks in plants. Metabolomics studies on nitrogen deprivation have shown that the metabolic profiles of plants change dramatically in response to nitrogen availability. Moreover, genetically-engineered plants with modified NUE show elevated levels of nitrogen-containing molecules. These preliminary findings indicate that metabolomics could offer a powerful approach for understanding plant $\mathrm{N}$ physiology and assist in strategies aimed at engineering NUE in crops. New methods that integrate metabolomics and computational approaches, such as quantitative trait locus mapping and flux balance analysis, offer a powerful new strategy for investigating the role that individual genes play in phenotypes. While there are still no FBA studies reported that analyze NUE on a whole plant scale, recent analyses of other plant phenotypes by FBA have demonstrated the feasibility of this approach. By using this integrative approach, we believe that NUE can be understood at an unprecedented level of detail. These insights are of global importance because they may result in more effective management of crops, better nutrient fertilization practices, and may ultimately lead to a new generation of engineered plants that make better use of the available nitrogen.

Acknowledgments: Allen G. Good received funding from Natural Sciences and Engineering Research Council (NSERC) and Bayer CropSciences (Edmonton, AB, Canada) through an NSERC Collaborative Research and Development (CRD) grant. I.L. is funded by Alberta Innovates-Health Solutions (AIHS, Translational Health Chair); Canada Foundation for Innovation (CFI-JELF 34986); and the Natural Sciences and Engineering Research Council (NSERC, Discovery Grant 04547). This review was an invited review and so was deemed free of charge. 
Author Contributions: Matthias S. Klein and Perrin H. Beatty conceived and designed the figures; Ian A. Lewis, Douglas G. Muench and Allen G. Good contributed analysis tools and original ideas; Perrin H. Beatty, Matthias S. Klein, Ian A. Lewis and Jeffrey J. Fischer contributed original ideas and wrote the paper.

Conflicts of Interest: The authors declare no conflict of interest. The founding sponsors had no role in the design of the study; in the collection, analyses, or interpretation of data; in the writing of the manuscript, and in the decision to publish the results.

\section{References}

1. Hawkesford, M.J.; Barraclough, P. An overview of nutrient use efficiency and strategies for crop improvement. In The Molecular and Physiological Basis of Nutrient Use Efficiency in Crops, 1st ed.; Hawkesford, M.J., Barraclough, P., Eds.; John Wiley \& Sons, Inc.: New Jersey, NJ, USA, 2011.

2. Good, A.G.; Beatty, P.H. Fertilizing nature: A tragedy of excess in the commons. PLoS Biol. 2011, 9, e1001124. [CrossRef] [PubMed]

3. Johnson, J.; Franzluebbers, A.J.; Weyers, S.L.; Reicosky, D.C. Agricultural opportunities to mitigate greenhouse gas emissions. Environ. Pollut. 2007, 150, 107-124. [CrossRef] [PubMed]

4. Montzka, S.; Dlugokencky, E.; Butler, J. Non- $\mathrm{CO}_{2}$ greenhouse gases and climate change. Nature 2011, 476, 43-50. [CrossRef] [PubMed]

5. Doney, S. The growing human footprint on coastal and open-ocean biogeochemistry. Science 2010, 328, 1512-1516. [CrossRef] [PubMed]

6. Gardner, J.; Drinkwater, L. The fate of nitrogen in grain cropping systems: A meta-analysis of ${ }^{15} \mathrm{~N}$ field experiments. Ecol. Appl. 2009, 19, 2167-2184. [CrossRef] [PubMed]

7. Antman, A.; Brubaek, S.; Andersen, B.H.; Lindqvist, K.; Markus-Johansson, M.; Sorensen, J.; Teerikangas, J. Nordic Agriculture Air and Climate; Nordic Council of Ministers: Copenhagen, Denmark, 2015.

8. McAllister, C.H.; Beatty, P.H.; Good, A.G. Engineering nitrogen use efficient crop plants: The current status. Plant Biotechnol. J. 2012, 10, 1011-1025. [CrossRef] [PubMed]

9. Britto, D.T.; Kronzucker, H.J. Bioengineering nitrogen acquisition in rice: Can novel initiatives in rice genomics and physiology contribute to global food security? BioEssays 2004, 26, 683-692. [CrossRef] [PubMed]

10. Pathak, R.R.; Lochab, S.; Raghuram, N. Improving plant nitrogen-use efficiency. In Comprehensive Biotechnology, 2nd ed.; Elsevier: Amsterdam, The Netherlands, 2011; Volume 4, pp. 209-218.

11. Amiour, N.; Imbaud, S.; Clément, G.; Agier, N.; Zivy, M.; Valot, B.; Balliau, T.; Armengaud, P.; Quilleré, I.; Cañas, R.; et al. The use of metabolomics integrated with transcriptomic and proteomic studies for identifying key steps in the control of nitrogen metabolism in crops such as maize. J. Exp. Bot. 2012, 63, 5017-5033. [CrossRef] [PubMed]

12. Shrawat, A.K.; Carroll, R.T.; DePauw, M.; Taylor, G.J.; Good, A.G. Genetic engineering of improved nitrogen use efficiency in rice by the tissue—specific expression of alanine aminotransferase. Plant Biotechnol. J. 2008, 6, 722-732. [CrossRef] [PubMed]

13. Kalaitzandonakes, N.; Alston, J.; Bradford, K. Compliance costs for regulatory approval of new biotech crops. Nat. Biotechnol. 2007, 25, 509-511. [CrossRef] [PubMed]

14. Rothstein, S.J.; Bi, Y.-M.; Coneva, V.; Han, M.; Good, A.G. The challenges of commercializing second-generation transgenic crop traits necessitate the development of international public sector research infrastructure. J. Exp. Bot. 2014. [CrossRef] [PubMed]

15. Simo, C.; Ibanez, C.; Valdes, A.; Cifuentes, A.; Garcia-Canas, V. Metabolomics of genetically modified crops. Int. J. Mol. Sci. 2014, 15, 18941-18966. [CrossRef] [PubMed]

16. Takehisa, H.; Sato, Y.; Antonio, B.A.; Nagamura, Y. Global transcriptome profile of rice root in response to essential macronutrient deficiency. Plant Signal. Behav. 2013, 8, e24409. [CrossRef] [PubMed]

17. Cai, H.; Lu, Y.; Xie, W.; Zhu, T.; Lian, X. Transcriptome response to nitrogen starvation in rice. J. Biosci. 2012, 37, 731-747. [CrossRef] [PubMed]

18. Humbert, S.; Subedi, S.; Cohn, J.; Zeng, B.; Bi, Y.M.; Chen, X.; Zhu, T.; McNicholas, P.D.; Rothstein, S.J. Genome-wide expression profiling of maize in response to individual and combined water and nitrogen stresses. BMC Genom. 2013, 14. [CrossRef] [PubMed] 
19. Ruuska, S.A.; Lewis, D.C.; Kennedy, G.; Furbank, R.T.; Jenkins, C.L.; Tabe, L.M. Large scale transcriptome analysis of the effects of nitrogen nutrition on accumulation of stem carbohydrate reserves in reproductive stage wheat. Plant Mol. Biol. 2008, 66, 15-32. [CrossRef] [PubMed]

20. Xu, Y.; Wang, R.; Tong, Y.; Zhao, H.; Xie, Q.; Liu, D.; Zhang, A.; Li, B.; Xu, H.; An, D. Mapping QTLs for yield and nitrogen-related traits in wheat: Influence of nitrogen and phosphorus fertilization on QTL expression. Theor. Appl. Genet. 2014, 127, 59-72. [CrossRef] [PubMed]

21. Senthilvel, S.; Vinod, K.K.; Malarvizhi, P.; Maheswaran, M. QTL and QTL $\times$ environment effects on agronomic and nitrogen acquisition traits in rice. J. Integr. Plant Biol. 2008, 50, 1108-1117. [CrossRef] [PubMed]

22. Coque, M.; Gallais, A. Genomic regions involved in response to grain yield selection at high and low nitrogen fertilization in maize. Theor. Appl. Genet. 2006, 112, 1205-1220. [CrossRef] [PubMed]

23. Fiehn, O.; Kopka, J.; Dörmann, P.; Altmann, T.; Trethewey, R.N.; Willmitzer, L. Metabolite profiling for plant functional genomics. Nat. Biotechnol. 2000, 18, 1157-1161. [CrossRef] [PubMed]

24. Tohge, T.; de Souza, L.P.; Fernie, A.R. Genome-enabled plant metabolomics. J. Chromatogr. B 2014, 966, 7-20. [CrossRef] [PubMed]

25. Grafahrend-Belau, E.; Weise, S.; Koschutzki, D.; Scholz, U.; Junker, B.H.; Schreiber, F. Metacrop: A detailed database of crop plant metabolism. Nucl. Acids Res. 2008, 36, D954-D958. [CrossRef] [PubMed]

26. Schlüter, U.; Mascher, M.; Colmsee, C.; Scholz, U.; Bräutigam, A.; Fahnenstich, H.; Sonnewald, U. Maize source leaf adaptation to nitrogen deficiency affects not only nitrogen and carbon metabolism but also control of phosphate homeostasis. Plant Physiol. 2012, 160, 1384-1406. [CrossRef] [PubMed]

27. Fiehn, O.; Weckwerth, W. Deciphering metabolic networks. Eur. J. Biochem. 2003, 270, 579-588. [CrossRef] [PubMed]

28. Edison, A.S.; Hall, R.D.; Junot, C.; Karp, P.D.; Kurland, I.J.; Mistrik, R.; Reed, L.K.; Saito, K.; Salek, R.M.; Steinbeck, C.; et al. The time is right to focus on model organism metabolomes. Metabolites 2016. [CrossRef] [PubMed]

29. Fukushima, A.; Kusano, M. Recent progress in the development of metabolome databases for plant systems biology. Front. Plant Sci. 2013. [CrossRef] [PubMed]

30. Tsugawa, H.; Cajka, T.; Kind, T.; Ma, Y.; Higgins, B.; Ikeda, K.; Kanazawa, M.; Vander Gheynst, J.; Fiehn, O.; Arita, M. MS-DIAL: Data-independent MS/MS deconvolution for comprehensive metabolome analysis. Nat. Methods 2015, 12, 523-526. [CrossRef] [PubMed]

31. Masclaux-Daubresse, C.; Daniel-Vedele, F.; Dechorgnat, J.; Chardon, F.; Gaufichon, L.; Suzuki, A. Nitrogen uptake, assimilation and remobilization in plants: Challenges for sustainable and productive agriculture. Ann. Bot. 2010, 105, 1141-1157. [CrossRef] [PubMed]

32. Osanai, T.; Oikawa, A.; Shirai, T.; Kuwahara, A.; Iijima, H.; Tanaka, K.; Hirai, M.Y. Capillary electrophoresis-mass spectrometry reveals the distribution of carbon metabolites during nitrogen starvation in Synechocstis sp. PCC 6803. Environ. Microbiol. 2014, 16, 512-524. [CrossRef] [PubMed]

33. Bölling, C.; Fiehn, O. Metabolite profiling of Chlamydomonas reinhardtii under nutrient deprivation. Plant Physiol. 2005, 139, 1995-2005. [CrossRef] [PubMed]

34. Wase, N.; Black, P.N.; Stanley, B.A.; DiRusso, C.C. Integrated quantitative analysis of nitrogen stress response in Chlamydomonas reinhardtii using metabolite and protein profiling. J. Proteome Res. 2014, 13, 1373-1396. [CrossRef] [PubMed]

35. Krapp, A.; Berthomé, R.; Orsel, M.; Mercey-Boutet, S.; Yu, A.; Castaings, L.; Daniel-Vedele, F. Arabidopsis roots and shoots show distinct temporal adaptation patterns toward nitrogen starvation. Plant Physiol. 2011, 157, 1255-1282. [CrossRef] [PubMed]

36. Meyer, R.C.; Steinfath, M.; Lisec, J.; Becher, M.; Witucka-Wall, H.; Torjek, O.; Fiehn, O.; Eckardt, A.; Willmitzer, L.; Selbig, J.; et al. The metabolic signature related to high plant growth rate in Arabidopsis thaliana. Proc. Natl. Acad. Sci. USA 2007, 104, 4759-4764. [CrossRef] [PubMed]

37. Ranathunge, K.; El-kereamy, A.; Gidda, S.; Bi, Y.M.; Rothstein, S.J. AMT1; 1 transgenic rice plants with enhanced $\mathrm{NH}_{4}{ }^{+}$permeability show superior growth and higher yield under optimal and suboptimal $\mathrm{NH}_{4}{ }^{+}$ conditions. J. Exp. Bot. 2014, 65, 965-979. [CrossRef] [PubMed]

38. Paez-Valencia, J.; Sanchez-Lares, J.; Marsh, E.; Dorneles, L.T.; Santos, M.P.; Sanchez, D.; Winter, A.; Murphy, S.; Cox, J.; Trzaska, M.; et al. Enhanced proton translocating pyrophosphatase activity improves nitrogen use efficiency in Romaine lettuce. Plant Physiol. 2013, 161, 1557-1569. [CrossRef] [PubMed] 
39. Fang, Z.; Xia, K.; Yang, X.; Grotemeyer, M.S.; Meier, S.; Rentsch, D.; Xu, X.; Zhang, M. Altered expression of the PTR/NRT1 homologue OsPTR9 affects nitrogen utilization efficiency, growth and grain yield in rice. Plant Biotechnol. J. 2013, 11, 446-458. [CrossRef] [PubMed]

40. Brauer, E.K.; Rochon, A.; Bi, Y.M.; Bozzo, G.G.; Rothstein, S.J.; Shelp, B.J. Reappraisal of nitrogen use efficiency in rice overexpressing glutamine synthetase 1. Physiol. Plant. 2011, 141, 361-372. [CrossRef] [PubMed]

41. Bao, A.; Zhao, Z.; Ding, G.; Shi, L.; Xu, F.; Cai, H. Accumulated expression level of cytosolic glutamine synthetase 1gene (OsGS1; 1 or OsGS1; 2) alter plant development and the carbon-nitrogen metabolic status in rice. PLoS ONE 2014, 9, e95581. [CrossRef]

42. Habash, D.Z.; Massiah, A.J.; Rong, H.L.; Wallsgrove, R.M.; Leigh, R.A. The role of cytosolic glutamine synthetase in wheat. Ann. Appl. Biol. 2001, 138, 83-89. [CrossRef]

43. Wang, Y.; Fu, B.; Pan, L.; Chen, L.; Fu, X.; Li, K. Overexpression of Arabidopsis Dof1, GS1 and GS2 Enhanced Nitrogen Assimilation in Transgenic Tobacco Grown Under Low-Nitrogen Conditions. Plant Mol. Biol. Rep. 2013, 31, 886-900. [CrossRef]

44. Chickova, S.; Arellano, J.; Vance, C.P.; Hernandez, G. Transgenic tobacco plants the overexpress alfalfa NADH-glutamate synthase have higher carbon and nitrogen content. J. Exp. Bot. 2001, 52, 2079-2087.

45. Ameziane, R.K.; Bernhard, R.B.; Lightfoot, D. Expression of the bacterial gdhA gene encoding NADPH glutamate dehydrogenase in tobacco affects plant growth and development. Plant Soil 2000, 221, 47-57. [CrossRef]

46. Brears, T.; Liu, C.; Knight, T.J.; Coruzzi, G.M. Ectopic overexpression of asparagine synthetase in transgenic tobacco. Plant Physiol. 1993, 103, 1285-1290. [PubMed]

47. Xia, T.; Xiao, D.; Liu, D.; Chai, W.; Gong, Q.; Wang, N.N. Heterologous expression of ATG8c from soybean confers tolerance to nitrogen deficiency and increases yield in Arabidopsis. PLoS ONE 2012, 7, e37217. [CrossRef] [PubMed]

48. Yanagisawa, S.; Akiyama, A.; Kisaka, H.; Uchimiya, H.; Miwa, T. Metabolic engineering with Dof1 transcription factor in plants: Improved nitrogen assimilation and growth under low-nitrogen conditions. Proc. Natl. Acad. Sci. USA 2004, 101, 7833-7888. [CrossRef] [PubMed]

49. Kurai, T.; Wakayama, M.; Abiko, T.; Yanagisawa, S.; Aoki, N.; Ohsugi, R. Introduction of the ZmDof1 gene into rice enhances carbon and nitrogen assimilation under low-nitrogen conditions. Plant Biotech. J. 2011, 9 , 826-837. [CrossRef] [PubMed]

50. He, H.; Liang, G.; Li, Y.; Wang, F.; Yu, D. Two young microRNAs originating from target duplication mediate nitrogen starvation adaptation via regulation of glucosinolate synthesis in Arabidopsis thaliana. Plant Physiol. 2014, 164, 853-865. [CrossRef] [PubMed]

51. Yan, Y.; Wang, H.; Hamera, S.; Chen, X.; Fang, R. miR444a has multiple functions in the rice nitrate-signaling pathway. Plant J. Cell Mol. Biol. 2014, 78, 44-55. [CrossRef] [PubMed]

52. Bi, Y.-M.; Kant, S.; Clarke, J.; Clark, J.; Gidda, S.; Ming, F.; Rothstein, S.J. Increased nitrogen-use efficiency in transgenic rice plants over-expressing a nitrogen-responsive early nodulin gene identified from rice expression profiling. Plant Cell Environ. 2009, 32, 1749-1760. [CrossRef] [PubMed]

53. Mohapatra, S.; Minocha, R.; Long, S.; Minocha, S.C. Transgenic manipulation of a single polyamine in poplar cells affects the accumulation of all amino acids. Amino Acids 2010, 38, 1117-1129. [CrossRef] [PubMed]

54. Pracharoenwattana, I.; Zhou, W.; Keech, O.; Francisco, P.B.; Udomchalothorn, T.; Tschoep, H.; Stitt, M.; Gibon, Y.; Smith, S.M. Arabidopsis has a cytosolic fumarase required for the massive allocation of photosynthate into fumaric acid and for rapid plant growth on high nitrogen. Plant J. Cell Mol. Boil. 2010, 62, 785-795. [CrossRef] [PubMed]

55. Fischer, J.J.; Beatty, P.H.; Good, A.G.; Muench, D.G. Review: Manipulation of microRNA Expression to Improve Nitrogen Use Efficiency. Plant Sci. 2013, 210, 70-81. [CrossRef] [PubMed]

56. Radchuk, R.; Radchuk, V.; Götz, K.P.; Weichert, H.; Richter, A.; Emery, R.J.; Weschke, W.; Weber, H. Ectopic expression of phosphoenolpyruvate carboxylase in Vicia narbonensis seeds: Effects of improved nutrient status on seed maturation and transcriptional regulatory networks. Plant J. Cell Mol. Boil. 2007, 51, 819-839. [CrossRef] [PubMed]

57. Ruan, C.; Shao, H.; Teixeira da Silva, J.A. A critical review on the improvement of photosynthetic carbon assimilation in C3 plants using genetic engineering. Crit. Rev. Biotech. 2012, 32, 1-21. [CrossRef] [PubMed] 
58. Work, V.; D'Adamo, S.; Radakovits, R.; Jinkerson, R.E.; Posewitz, M.C. Improving photosynthesis and metabolic networks for the competitive production of phototroph-derived biofuels. Curr. Opin. Biotech. 2012, 23, 290-297. [CrossRef] [PubMed]

59. Bar-Peled, M.; O’Neill, M. Plant nucleotide-sugar formation, interconversion, and salvage by sugar recycling. Ann. Rev. Plant Biol. 2011, 62, 127-155. [CrossRef] [PubMed]

60. Bi, Y.; Wang, R.L.; Zhu, T.; Rothstein, S.J. Global transcription profiling reveals differential responses to chronic nitrogen stress and putative nitrogen regulatory components in Arabidopsis. BMC Genom. 2007, 8. [CrossRef] [PubMed]

61. Gutiérrez, R.A.; Stokes, T.L.; Thum, K.; Xu, X.; Obertello, M.; Katari, M.S.; Tanurdzic, M.; Dean, A.; Nero, D.C.; McClung, C.R. Systems approach identifies an organic nitrogen-responsive gene network that is regulated by the master clock control gene CCA1. Proc. Natl. Acad. Sci. USA 2008, 105, 4939-4944. [CrossRef] [PubMed]

62. Midorikawa, K.; Kuroda, M.; Terauchi, K.; Hoshi, M.; Ikenaga, S.; Ishimaru, Y.; Abe, K.; Asakura, T. Additional nitrogen fertilization at heading time of rice down-regulated cellulose synthesis in seed endosperm. PLoS ONE 2014, 9, e98738. [CrossRef] [PubMed]

63. Guevara, D.; El-Kereamy, A.; Yaish, M.W.; Mei-Bi, Y.; Rothstein, S.J. Functional Characterization of the Rice UDP-glucose 4-epimerase 1, OsUGE1: A Potential role in cell wall carbohydrate partitioning during limiting nitrogen conditions. PLoS ONE 2014, 9, e96158. [CrossRef] [PubMed]

64. Liu, H.; Dai, X.Y.; Xu, Y.Y.; Chong, K. Over-expression of OsUGE-1 altered raffinose level and tolerance to abiotic stress but not morphology in Arabidopsis. J. Plant Physiol. 2007, 164, 1384-1390. [CrossRef] [PubMed]

65. Li, N.; Wang, L.; Zhang, W.; Takechi, K.; Takano, H.; Lin, X. Overexpression of UDP-glucose pyrophosphorylase from Larix gmelinii enhances vegetative growth in transgenic Arabidopsis thaliana. Plant Cell Rep. 2014, 33, 779-791. [CrossRef] [PubMed]

66. Wang, X.; Li, Y.; Fang, G.; Zhao, Q.; Zeng, Q.; Li, X.; Gong, H.; Li, Y. Nitrite promotes the growth and decreases the lignin content of indica rice calli: A comprehensive transcriptome analysis of nitrite-responsive genes during in vitro culture of rice. PLoS ONE 2014, 9, e95105. [CrossRef] [PubMed]

67. Kim, H.K.; Choi, Y.H.; Verpoorte, R. NMR-based plant metabolomics: Where do we stand, where do we go? Trends Biotech. 2011, 29, 267-275. [CrossRef] [PubMed]

68. Mesnard, F.; Ratcliffe, R.G. NMR analysis of plant nitrogen metabolism. Photosynth. Res. 2005, 83, 163-180. [CrossRef] [PubMed]

69. Gronwald, W.; Klein, M.S.; Kaspar, H.; Fagerer, S.R.; Nürnberger, N.; Dettmer, K. Urinary metabolite quantification employing 2D NMR spectroscopy. Anal. Chem. 2008, 23, 9288-9297. [CrossRef] [PubMed]

70. Lewis, I.A.; Schommer, S.C.; Hodis, B.; Robb, K.A.; Tonelli, M.; Westler, W.M. Method for determining molar concentrations of metabolites in complex solutions from two-dimensional ${ }^{1} \mathrm{H}_{-}{ }^{13} \mathrm{C}$ NMR spectra. Anal. Chem. 2007, 79, 9385-9390. [CrossRef] [PubMed]

71. Wishart, D.S. Quantitative metabolomics using NMR. Trends Anal. Chem. 2008, 27, 228-237. [CrossRef]

72. Fan, T.W.; Lane, A.N.; Higashi, R.M. In Vivo and In Vitro Metabolomic Analysis of Anaerobic Rice Coleoptiles Revealed Unexpected Pathways. Russ. J. Plant Physiol. 2003, 50, 787-793. [CrossRef]

73. Hinse, C.; Richter, C.; Provenzani, A.; Stöckigt, J. In vivo monitoring of alkaloid metabolism in hybrid plant cell cultures by 2D cryo-NMR without labelling. Bioorg. Med. Chem. 2003, 11, 3913-3919. [CrossRef]

74. Aubert, S.; Hennion, F.; Bouchereau, A.; Gout, E.; Bligny, R.; Dorne, A.-J. Subcellular compartmentation of proline in the leaves of the subantarctic Kerguelen cabbage Pringlea antiscorbutica R. Br. In vivo ${ }^{13} \mathrm{C}-\mathrm{NMR}$ study. Plant Cell Environ. 1999, 22, 255-259. [CrossRef]

75. Chiwocha, S.D.; Abrams, S.R.; Ambrose, S.J.; Cutler, A.J.; Loewen, M.; Ross, A.R.; Kermode, A.R. A method for profiling classes of plant hormones and their metabolites using liquid chromatography-electrospray ionization tandem mass spectrometry: An analysis of hormone regulation of thermodormancy of lettuce (Lactuca sativa L.) seeds. Plant J. 2003, 35, 405-417. [CrossRef] [PubMed]

76. Nicholson, G.; Rantalainen, M.; Li, J.V.; Maher, A.D.; Malmodin, D.; Ahmadi, K.R.; Faber, J.H.; Barrett, A.; Min, J.L.; Rayner, N.W.; et al. A genome-wide metabolic QTL analysis in Europeans implicates two loci shaped by recent positive selection. PLoS Genet. 2011, 7, e1002270. [CrossRef]

77. Lane, A.N.; Fan, T.W.; Higashi, R.M. Isotopomer-based metabolomic analysis by NMR and mass spectrometry. Biophys. Tools Biol. 2008, 84, 541-588. 
78. Nelson, C.J.; Alexova, R.; Jacoby, R.P.; Millar, A.H. Proteins with High Turnover Rate in Barley Leaves Estimated by Proteome Analysis Combined with in Planta Isotope Labeling. Plant Physiol. 2014, 166, 91-108. [CrossRef] [PubMed]

79. Fan, T.W.-M.; Lane, A.N. NMR-based stable isotope resolved metabolomics in systems biochemistry. J. Biomol. NMR 2011, 49, 267-280. [CrossRef] [PubMed]

80. Lee, J.M.; Gianchandani, E.P.; Papin, J.A. Flux balance analysis in the era of metabolomics. Brief Bioinform. 2006, 7, 140-150. [CrossRef] [PubMed]

81. Edwards, J.S.; Palsson, B.O. Metabolic flux balance analysis and the in silico analysis of Escherichia coli K-12 gene deletions. BMC Bioinform. 2000, 1. [CrossRef] [PubMed]

82. Ke, H.; Lewis, I.A.; Morrisey, J.M.; McLean, K.J.; Ganesan, S.M.; Painter, H.J.; Mather, M.W.; Jacobs-Lorena, M.; Llinas, M.; Vaidya, A.B. Genetic investigation of tricarboxylic acid metabolism during the Plasmodium falciparum life cycle. Cell Rep. 2015, 11, 164-174. [CrossRef] [PubMed]

83. Yuan, J.; Fowler, W.U.; Kimball, E.; Lu, W.; Rabinowitz, J.D. Kinetic flux profiling of nitrogen assimilation in Escherichia coli. Natl. Chem. Biol. 2006, 2, 529-530. [CrossRef] [PubMed]

84. Grafahrend-Belau, E.; Junker, A.; Eschenroder, A.; Muller, J.; Schreiber, F.; Junker, B.H. Multiscale Metabolic Modeling: Dynamic Flux Balance Analysis on a Whole-Plant Scale. Plant Physiol. 2013, 163, 637-647. [CrossRef] [PubMed]

85. Resendis-Antonio, O.; Reed, J.L.; Encarnacion, S.; Collado-Vides, J.; Palsson, B. Metabolic reconstruction and modeling of nitrogen fixation in Rhizobium etli. PLoS Comput. Biol. 2007, 3. [CrossRef] [PubMed]

86. Shaw, R.; Kundu, S. Flux balance analysis of genome-scale metabolic model of rice (Oryza sativa): Aiming to increase biomass. J. Biosci. 2015, 40, 819-828. [CrossRef] [PubMed]

87. Sweetlove, L.J.; Ratcliffe, R.G. Flux-Balance Modeling of Plant Metabolism. Front. Plant Sci. $2011,2$. [CrossRef] [PubMed]

88. Dal'Molin, C.G.; Quek, L.E.; Palfreyman, R.W.; Brumbley, S.M.; Nielsen, L.K. C4gem, a genome-scale metabolic model to study c4 plant metabolism. Plant Physiol. 2010, 154, 1871-1885. [CrossRef] [PubMed]

89. Simons, M.; Saha, R.; Guillard, L.; Clement, G.; Armengaud, P.; Canas, R.; Maranas, C.D.; Lea, P.J.; Hirel, B. Nitrogen-use efficiency in maize (Zea mays 1.): From 'omics' studies to metabolic modelling. J. Exp. Bot. 2014, 65, 5657-5671. [CrossRef] [PubMed]

90. Braune, H.; Müller, J.; Diepenbrock, W. Measurement and Modelling Awn Photosynthesis of Barley (Hordeum vulgare L.) for Virtual Crop Models. Pflanzenbauwissenschaften 2007, 11, 10-15.

91. Good, A.G.; Beatty, P.H. Biotechnological Approaches to Improving Nitrogen Use Efficiency in Plants: Alanine Aminotransferase as a Case Study. In The Molecular and Physiological Basis of Nutrient Use Efficiency in Crops, 1st ed.; Hawkesford, M.J., Barraclough, P., Eds.; John Wiley \& Sons, Inc.: New Jersey, NJ, USA, 2011. 